\title{
Distribution, speciation and composition of humic substances in a macro-tidal temperate estuary
}

\author{
Riso Ricardo 1, Mastin Manon 2, Aschehoug Arthur 1, Davy Romain 2, Devesa Jeremy ${ }^{1}$, \\ Laes Huon Agathe ${ }^{2}$, Waeles Mathieu ${ }^{1}$, Dulaquais Gabriel 2, ${ }^{*}$
}

${ }^{1}$ Laboratoire des Sciences de l'environnement Marin, Institut Universitaire Européen de la Mer, CNRS/IRD/UBO/IFREMER (UMR 6539), Place Nicolas Copernic, F-29280, Plouzané, France

${ }^{2}$ Laboratoire Détection Capteurs et Mesures, Unité de Recherches et Développements

Technologiques, Ifremer, France

*Corresponding author : Gabriel Dulaquais, email address : Gabriel.dulaquais@univ-brest.fr

\begin{abstract}
:
In aquatic environments, the term humic substances (HS) encompasses terrestrial and autochthonous refractory organic matter. HS are one of the main fractions of natural organic matter and are important chelators of trace elements. In environmental studies, the determination of HS is often restricted to the dissolved fraction, and the content of HS in the suspended particles remains unknown. In this work, we present the composition and dynamics of HS along the mixing gradient of a macrotidal estuary in both the dissolved and particulate fraction. After the isolation of particulate HS using a solid-liquid alkali extraction method, HS were characterized by size exclusion chromatography (SEC) and electrochemical methods. The method, validated using a certified reference material, demonstrated a low detection limit ( $\mu g-C L-1)$, a good repeatability $(7.7 \%)$ an excellent reproducibility $(1.3 \%)$ and was poorly prone to contamination (filter blank $<1 \mu \mathrm{g}-\mathrm{C}$ ). Analyses of environmental samples showed a particulate fraction contributing significantly to the total humic pool in the estuary (3-20\%) and representing up to $35 \%$ of electroactive HS. Phase transfers from the dissolved to the particulate fraction were observed and the electroactive HS were strongly affected in the maximum turbidity zone. Multi-detection SEC analyses showed differences in the molecular composition between the dissolved and particulate fractions. Particulate HS were more nitrogen-rich and electroactive than dissolved HS. The non-conservative changes in the composition of $\mathrm{HS}$ along the land-sea continuum evidence the existence of abiotic and biotic processes that altered HS during their transit from river to marine waters.
\end{abstract}




\section{Graphical abstract}

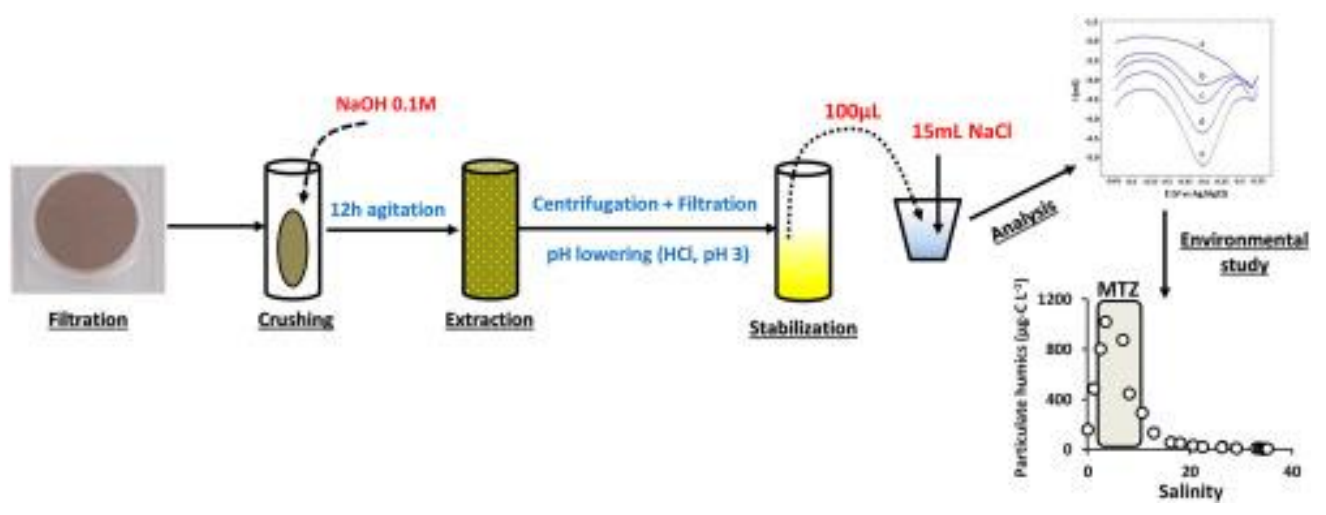

\section{Highlights}

- A simple method for the determination of humic substances in suspended particulate matter is developed and validated. Application of the method to estuarine samples allows the quantification and the characterization of particulate humic substances along the entire land-sea continuum of a temperate system. Internal abiotic and biotic estuarine processes alter the chemical composition of humic substances during estuarine mixing.

Keywords : Humic substances, estuary, suspended particulate matter, biogeochemistry 


\section{Introduction}

Humification is the process that transforms detritic organic matter originating from plant and animal decomposition into "humus". It is a complex process not well understood. The most commonly accepted hypothesis is that it would be controlled by physicochemical, biochemical and microbiological reactions that lead to the formation of aromatic and aliphatic compounds: humic substances (HS) (Stevenson, 1994). HS are traditionally recovered from soils via successive chemical processing and extractions. After extraction, they can be operationally defined in three groups of compounds: humins are insoluble at any $\mathrm{pH}$, humic acids (HA) are insoluble at $\mathrm{pH}<1$ and fulvic acids (FA) soluble at any $\mathrm{pH}$ (Thurman and Malcolm, 1981; Moreda-Piñeiro et al., 2006). In aquatic ecosystems, HS accounts for up to $20 \%$ of the dissolved organic matter in ocean waters (Hessen and Tranvik, 1998; Dulaquais et al., 2018a) and between 30 and 80\% in estuarine waters (Dittmar and Kattner, 2003; Waeles et al., 2013; Dulaquais et al., 2018b). HS are therefore one of the main fractions composing dissolved organic matter playing a key role in aquatic biogeochemistry. Among others, HS increase the solubility of organic contaminants (Tanaka et al., 1997; Blasioli et al., 2008) and stimulate the growth of some dinoflagellates (Gagnon et al., 2005). Moreover there is a growing interest in their important role as complexing ligands of essential trace metals such as iron (Laglera et al., 2011, Bundy et al., 2015, Dulaquais et al., 2018b, Whitby et al., 2020) and copper (Voelker and Kogut, 2001; Shank et al., 2004; Waeles et al., 2015, Dulaquais et al 2020). Quantitative analysis of HS is not easy. It involves the determination of a class of operationally defined compounds. Moreover the definition of HS is also method dependent (e.g. fluorescent vs chromatographic isolation) making it difficult to compare results between different studies using different analytical methods. The study of HS can also be confusing to follow due to a complex terminology thereby the terminology used in this study is synthetized in Table 1. In this study we In order to overcome this issue, the scientific community has implemented the use of common standards for calibration (Fillela, 2014). Those standards are provided by the International Humic Substance Society (IHSS) with known elemental composition and chemical properties.

Different analytical techniques allow the quantification of HS in natural waters. The most commonly used are size exclusion chromatography (SEC) (Hubert et al., 2011, Abbt-Braun et al., 2004, Dulaquais et al., 2018b), UV-visible and fluorescence spectroscopy (Senesi, 1990, Miano, 1992, Coble, 1996, Parlanti et al., 2000, Leenheer and Croué, 2003) as well as electrochemical methods (Quentel at al., 1986, Chanudet et al., 2006, Laglera et al., 2007; 
Whitby and van den Berg, 2015, Sukekava et al., 2018). While SEC methods allow the determination of total HS carbon concentrations, fluorescence spectroscopy monitors the transformation of HS, and electrochemical methods provide information on the capacity of HS to complex trace elements. The development of these methodologies led to the publication of a large number of studies on the behaviour of dissolved HS in riverine, estuarine and coastal waters. In the case of macrotidal temperate estuaries, Waeles et al., (2013) studied the seasonal variations of dissolved electroactive HS (deHS) in an estuary prone to a high anthropogenic pressure from agricultural activities. Their results demonstrated that high levels of deHS (> $3 \mathrm{mg}-\mathrm{C} \mathrm{L} \mathrm{L}^{-1}$ ) were associated with periods of the first seasonal high floods confirming the terrestrial origin of estuarine HS and the significant mobilization of eHS from soil by drainage in early fall. Waeles et al., (2013) also showed a quasi-conservative behaviour of deHS along the estuary most of the year but proposed that flocculation processes could induce non-conservative distributions. Similar results were reported in several estuarine systems by analysing either deHS or total dissolved HS (dHS) (Sholkovitz et al., 1978, Ertel et al., 1986, Huguet et al 2009, Asmala et al., 2014, Marie et al., 2017). To date, the analysis of HS in natural waters has been carried out mainly in the dissolved phase and only a restricted number of studies have focused on the particulate phase. Calace, et al. (2006) investigated particulate HS (pHS) in the Venice canals and in the Ross Sea (2010). These authors determined pHS concentrations as the difference between unfiltered and filtered samples and the extraction used to recover pHS was long, arduous and may not be the most appropriate technique for large-scale studies.

Quantification of pHS in estuarine and marine waters is of particular interest for several reasons. First, to our knowledge, there are only few published data on the levels and distribution of pHS along the entire land-sea continuum (Hair and Bassett, 1973; Harvey and Mannino, 2001) and there are so far no published data on peHS in estuaries. Secondly, studies conducted in estuarine ecosystems highlighted the extended role of deHS on the complexation and thus on the speciation of trace metal elements (Laglera et al., 2011, Bundy et al., 2015, Abualhaija et al., 2015, Dulaquais et al., 2019). Hence, understanding phase transfers of HS and eHS along the salinity gradient will help to better constrain the estuarine biogeochemistry of trace metals. Recent works in the oceanic environment have also shown that deHS account for between 4 and 15\% of dHS and play a key role in the biogeochemical cycle of trace metals such as iron (Dulaquais et al., 2018a; Sukekava et al., 2018; Whitby et al., 2020). Unfortunately, without any data the role of peHS on trace element biogeochemistry in the marine environment cannot be established. 
In this context, this work presents a simple method combining solid-liquid alkali extraction followed by electrochemical and multi-detection SEC analyses for the quantification of humic matter in suspended particulate matter. Our results provide the first speciation study of HS within (electroactive versus total) and between (dissolved versus particulate) fractions along the land-sea continuum of a macro-tidal estuary.

Table 1. Definitions and terminology used to describe humic substances in this study.

\begin{tabular}{|c|c|c|c|}
\hline Abbreviation & Term & Definition & Type of measurement \\
\hline HA & Humic acids & Humic substances insoluble at a $\mathrm{pH}<1$ & $\begin{array}{l}\text { DOC analysis after isolation onto } \\
\text { DAX-8 resin and precipitation at } \mathrm{pH}< \\
1\end{array}$ \\
\hline FA & Fulvic acids & Humic substances soluble at any $\mathrm{pH}$ & $\begin{array}{l}\text { DOC analysis after isolation onto } \\
\text { DAX-8 resin }\end{array}$ \\
\hline $\mathrm{dHS}$ & $\begin{array}{l}\text { Dissolved humic } \\
\text { substances }\end{array}$ & $\begin{array}{l}\text { Encompasses FA \& HA in the } \\
\text { dissolved fraction. }\end{array}$ & $\begin{array}{l}\text { Direct DOC analysis by size } \\
\text { exclusion chromatography. Similar to } \\
\text { XAD-8 extraction }\end{array}$ \\
\hline deHS & $\begin{array}{l}\text { Dissolved } \\
\text { electroactive } \\
\text { humic substances }\end{array}$ & $\begin{array}{l}\text { Electroactive fraction of dissolved } \\
\text { humic substances. This fraction is a } \\
\text { proxy of the binding capacity of } \\
\text { dissolved humic matter for trace } \\
\text { elements }\end{array}$ & $\begin{array}{l}\text { Direct by cathodic stripping } \\
\text { voltammetry }\end{array}$ \\
\hline $\mathrm{pHS}$ & $\begin{array}{l}\text { Particulate humic } \\
\text { substances }\end{array}$ & $\begin{array}{l}\text { Encompasses FA \& HA extractable in } \\
\text { the particulate fraction. }\end{array}$ & $\begin{array}{l}\text { Collection, } \mathrm{NaOH} \text { extraction and } \\
\text { analysis by Size exclusion } \\
\text { chromatography after dilution in } \\
\text { Ultrapure water }\end{array}$ \\
\hline peHS & $\begin{array}{l}\text { Particulate } \\
\text { electroactive } \\
\text { humic substances }\end{array}$ & $\begin{array}{l}\text { Electroactive fraction of particulate } \\
\text { humic substances. This fraction is a } \\
\text { proxy of the binding capacity of } \\
\text { particulate humic matter for trace } \\
\text { elements }\end{array}$ & $\begin{array}{l}\text { Cathodic stripping voltammetry after } \\
\text { dilution in Ultrapure }+\mathrm{NaCl} 0.55 \mathrm{M} \\
\text { solution }\end{array}$ \\
\hline
\end{tabular}




\section{Material and methods}

\subsection{Sampling}

For analytical tests, a freshwater sample was used. This sample was collected on January 14, 2019, in the Aulne River (France). The sample was collected from the shoreline using a precleaned polypropylene beaker placed at the end of a 3-meter pole. Immediately after sampling, the sample was placed in a rinsed with ultrapure water (resistivity > 18.2 $\mathrm{M} \Omega$, Milli-Q Element System, Millipore ${ }^{\circledR}$, called UP-water hereafter) and acid cleaned $(0.01 \mathrm{M}$, $\mathrm{HCl}$, suprapure $\AA$, Merck) 5 L HDPE (Nalgène $\AA$ ) bottle, rinsed several times with the water sample. The bottle was kept at $4^{\circ} \mathrm{C}$ in the dark until filtration (Calcined, $450^{\circ} \mathrm{C}$ for $4 \mathrm{~h}, \mathrm{GF} / \mathrm{F}$ $25 \mathrm{~mm}$ filters Whatman $\left.{ }^{\circledR}\right)$ at the lab, operated 2 hours after sampling. The speciation study of HS in estuarine and coastal waters was operated on 20 sub-surface ( $0.5 \mathrm{~m}$ depth) samples collected in the Aulne estuary (France) covering the entire land-sea continuum from the Aulne River in Châteaulin to the offshore waters of the Crozon peninsula (Figure 1). Sampling was carried out during the FeLINE cruise (Fe LIgands in the AulNe Estuary) onboard RV Hésione (INSU-CNRS-UBO) during a low discharge period $\left(4.8 \mathrm{~m}^{3} \mathrm{~s}^{-1}\right)$ on October 22, 2018. This water flow was among the lowest of the year $\left(1-232 \mathrm{~m}^{3} \mathrm{~s}^{-1}\right)$ and was preceded by 5 months of low water regime. This choice of water regime was made in order to have a significantly longer residence time of the waters in the estuary ( 30 days) than the timescale of sampling (6 hours) allowing a better visualization of the biogeochemical processes occurring in the estuary. Salinity (S), pH (NBS scale) and $\mathrm{O}_{2}$ were measured in situ using an AQUAread AP2000 probe calibrated on the day of sampling. The accuracy of the measurements is $\pm 0.1 \mathrm{~g} \mathrm{~kg}^{-}$

${ }^{1}, \pm 0.05 \mathrm{pH}$ units and $0.1 \mathrm{mg} ; \mathrm{L}^{-1}$ for the three parameters, respectively. The salinity and $\mathrm{pH}$ of the samples were re-measured in the lab at $25^{\circ} \mathrm{C}$ after filtration.

Water samples were collected by hand wearing long plastics gloves (Polysen ${ }^{\circledR}, 92 \mathrm{~cm}$ ) in 500 $\mathrm{mL}$ glass bottles $\left(\right.$ Schott $\left.{ }^{\circledR}\right)$ previously washed with acidified UP-water $(0.01 \mathrm{M} \mathrm{HCl})$ and precombusted $\left(4 \mathrm{~h}, 450^{\circ} \mathrm{C}\right)$. Water samples were filtered on precombusted $\left(450^{\circ} \mathrm{C}, 4 \mathrm{~h}\right) \mathrm{GF} / \mathrm{F}$ $(25 \mathrm{~mm}$ Whatman $\AA)$ filters back at the laboratory, approximately 2 hours after sampling. The water samples were collected in precombusted glass vials $\left(4 \mathrm{~h}, 450^{\circ} \mathrm{C}\right)$. dHS samples were kept at natural $\mathrm{pH}$ and analysed subsequently after filtration by SEC while aliquots for deHS 
determination were acidified $(0.01 \mathrm{M} \mathrm{HCl})$ and kept at $4^{\circ} \mathrm{C}$ in the dark until analysis. The filters were stored in precombusted glass vials at $-20^{\circ} \mathrm{C}$ until their use for the determination of peHS and pHS

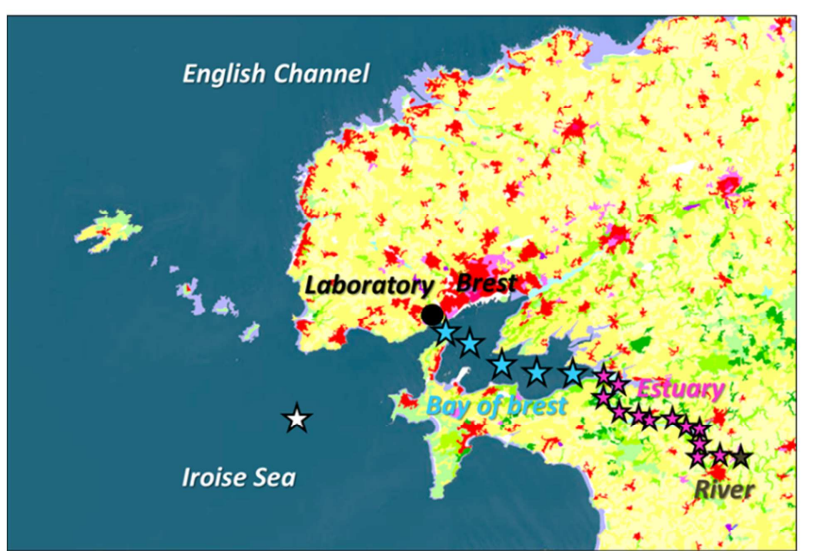

Sampling $S=0$ Sampling $1<S<28$ Sampling $28<S<34$ Sampling $S=35$

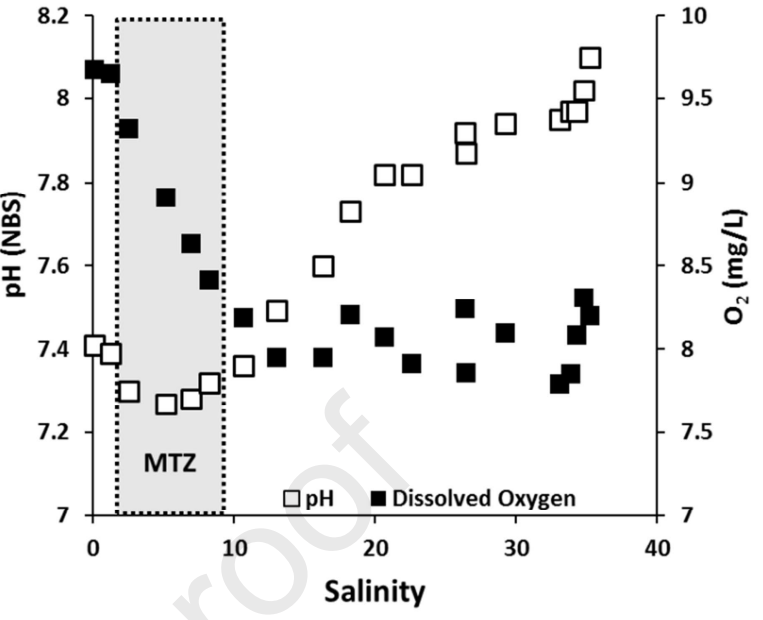

Figure 1. Map of sampling location during the FELINE program. The location of the laboratory is also indicated. $\mathrm{pH}$ (open squares) and $\mathrm{O}_{2}$ (dark squares) distribution with salinity in the Aulne estuary during sampling. The Large grey square indicates the location of the maximum turbidity zone (MTZ) during sampling.

Macrotidal estuaries, such as the Aulne estuary, are characterized by a physical zone where fresh surface waters and marine bottom waters meet, the so-called maximum turbidity zone (MTZ). In the MTZ suspended particles brought by the river are blocked and sediments resuspended (Brenon and Le Hir, 1999). The MTZ is particularly enriched in particulate organic matter (Basoulet, 1979; Abril et al., 2002) and constitutes a physico-chemical and biogeochemical "reactor" where phase transfers can take place. The position of the MTZ depends on the hydrological state of the river and the strength of the tide (Brenon and Le Hir, 1999; Middelburg and Herman, 2007; Savoye et al., 2012; Waeles et al., 2013). The part of the estuary where dissolved oxygen decreased significantly and the $\mathrm{pH}$ values were the lowest (Figure 1) corresponded to the maximum turbidity zone (MTZ) as already observed in other estuaries (Amann et al., 2014). Particle load on the filters for a given volume further evidenced the MTZ location in this zone (data not shown).

\subsection{Analysis}

\subsubsection{Analysis of dissolved and particulate electroactive humic substances}

Electroactive humic substances (eHS) are defined as the fraction of HS able to complex trace elements (Dulaquais et al., 2018a,, 2020; Sukekava et al, 2018,). eHS analyses were operated on the particulate (peHS) and the dissolved (deHS) fractions. In both cases the analytical 
method used was a differential pulse cathodic stripping polarography method (DP-CSV), developed by Quentel et al., (1986). This simple and rapid method, based on the adsorption of the complex formed by eHS with molybdenum on the working electrode, has been used in marine, estuarine and coastal waters (Chanudet et al., 2006, Waeles et al., 2013, PernetCoudrier et al. 2013, Marie et al., 2017; Dulaquais et al., 2018a; Gao and Guéguen, 2018). Analyses were made with a $\mu$-AutolabIII potentiostat-galvanostat controlled by GPES 4.9 software and operating on a three-electrode system. The working electrode is a static mercury drop electrode (SMDE), Metrohm model $663 \mathrm{VA}$, with a drop size of $0.52 \mathrm{~mm}^{2}$. The reference electrode in an $\mathrm{Ag} / \mathrm{AgCl}$ electrode $\left(3 \mathrm{~mol} \mathrm{~L}^{-1} \mathrm{KCl}\right.$, Suprapur®) and the auxiliary electrode is a platinum electrode. To perform the analysis of deHS, $300 \mathrm{nmol} \mathrm{L}{ }^{-1}$ of Mo(VI) were added to $15.00 \pm 0.01 \mathrm{~g}$ of sample (weighed in a laminar flow bench) and adjusted to a $\mathrm{pH}$ of $2.00 \pm 0.05(\mathrm{HCl})$. After a degassing period of $300 \mathrm{~s}\left(\mathrm{~N}_{2} \geq 99.999 \%\right.$ ALPHAGAZ $^{\mathrm{TM}}$, Air liquid $\left.{ }^{\circledR}\right)$, under agitation, a deposition potential of $-0.25 \mathrm{~V}$ was applied for a period of 30 to $120 \mathrm{~s}$, depending on the concentration of eHS in the sample. Under these conditions the Mo(VI)-eHS complex was adsorbed on the working electrode and simultaneously reduced to Mo(V)-eHS. After an equilibration period without agitation of $15 \mathrm{~s}$, a cathodic sweep of the potential was carried out between -0.25 and $-0.65 \mathrm{~V}$ in the differential pulse mode. During the cathodic scan the Mo(V)-eHS complex was further reduced into Mo(IV) produced a quantifiable cathodic current proportional to the amount of eHS adsorbed and thus to the concentration of deHS in solution. The following electrochemical parameters were used : Modulation time $0.05 \mathrm{~s}$; Interval time $0.1 \mathrm{~s}$; Step potential $2 \mathrm{mV}$; Modulation amplitude 0.06 $\mathrm{V}$ and Scan rate $19.5 \mathrm{mV} \mathrm{s}^{-1}$. The analytical treatment of UV-irradiated seawater did not show a quantifiable peak at the eHS potential $(-0.4 \mathrm{~V}$ vs $\mathrm{Ag} / \mathrm{AgCl})$, ensuring no contamination during the different steps of the analysis.

For peHS analysis, the $300 \mathrm{nmol} . \mathrm{L}^{-1}$ of $\mathrm{Mo}(\mathrm{VI})$ were added to $15.00 \pm 0.01 \mathrm{~g}$ of a $0.55 \mathrm{M}$ $\mathrm{NaCl}$ (Suprapur® grade solid, Merck) solution, acidified at pH $2.00 \pm 0.05(\mathrm{HCl})$ which was used as electrolyte. Once the electrochemical measurement carried out to check the purity of the electrolyte (Figure 2a), a variable quantity of the pHS extract (see extraction procedure, section 2.4) was added to the electrochemical cell. The added volume, between 100 and 1000 $\mu \mathrm{L}$, was adjusted by increment of $100 \mu \mathrm{L}$ until the peak signal reached $\sim$ 1nA. All electrochemical parameters for peHS determination were identical to those used for deHS analysis.

For each analysis, three standard additions of the $38.15 \mathrm{mg}-S R F A ~ L^{-1}$ (international standard Suwannee River Fulvic Acid, SRFA 1S101F) solution were made. This solution was prepared 
by diluting a $256.12 \mathrm{mg}$ SRFA L ${ }^{-1}$ stock solution (prepared by dissolving a dried mass of SRFA in $0.1 \mathrm{M} \mathrm{NaOH}$ solution). Final concentration was monitored by SEC analysis. After each addition, three adsorption - redissolution cycles were performed, producing a 12-point calibration curve. Each addition was followed by a $15 \mathrm{~s}$ degassing step. It is worth noting that all the curves obtained were linear with a correlation coefficient $\left(R^{2}>0.995\right)$. All data are provided in equivalent of SRFA ( $\mu$ g-eqSRFA) with standard errors (SE) calculated by error propagation using the error of the LINEST Excel® function. The reproducibility of the method was assessed on the basis of eight non-consecutive analyses of the same natural coastal sea water (Bay of Brest). The mean concentration (mean \pm SE) was $387 \pm 25 \mu \mathrm{g}$ eqSRFA $\mathrm{L}^{-1}$ corresponding to a reproducibility of $6 \%$. Repeatability was calculated as the relative SE of 11 consecutive measurements on a $15.0 \mathrm{ml}$ sample of natural coastal seawater. Repeatability was about $2 \%$. A detection limit (LOD) was calculated and defined as $3 \times$ SE, with "SE" being the mean of the standard error of the 11 consecutive measurements. For a deposition time of $120 \mathrm{~s}$, the detection limit was $23 \mu \mathrm{g}$-eqSRFA $\mathrm{L}^{-1}$. Figure $2 \mathrm{a}$ shows an example of the electrochemical analysis of peHS samples.

(a)

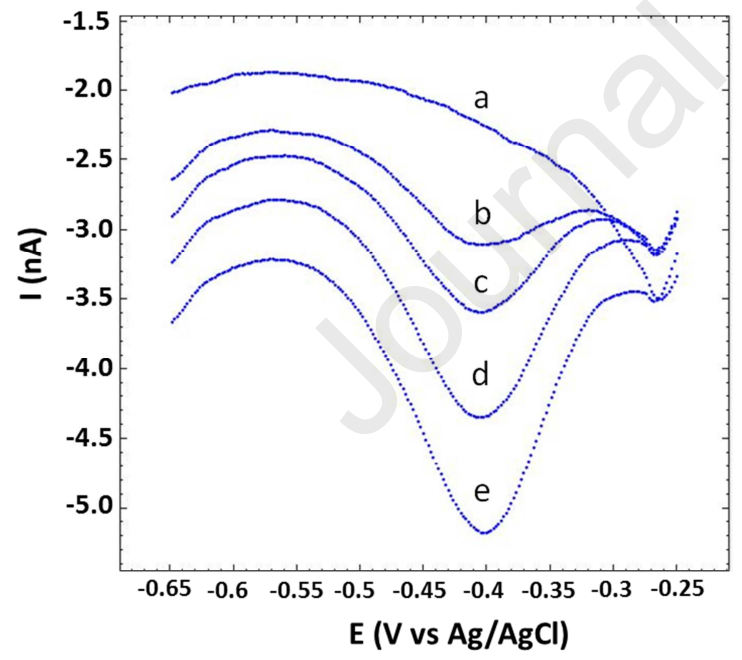

(b)

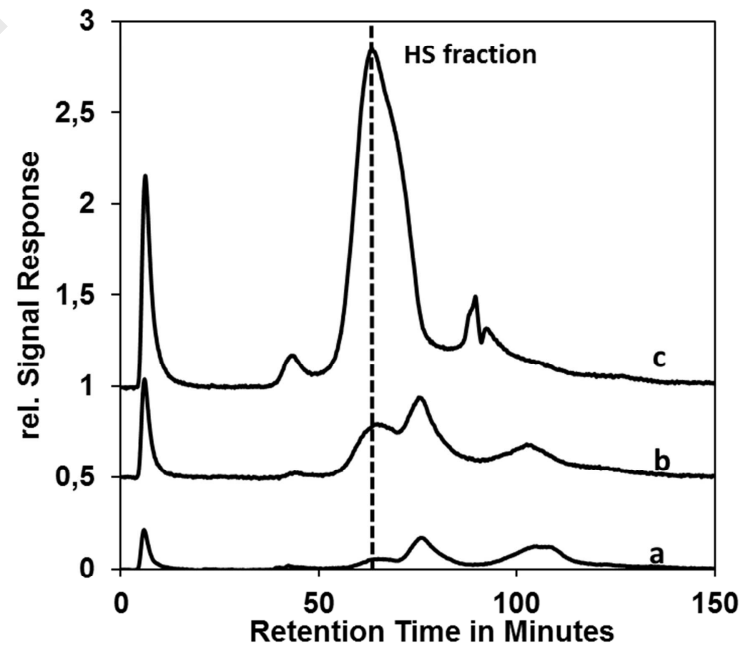

Figure 2. (a) Analysis of peHS in an estuarine sample by the electrochemical method. a) $\mathrm{NaCl} 0.55 \mathrm{M} \mathrm{pH}=$ $2.00 \pm 0.05(\mathrm{HCl}) ; \mathrm{b})+100 \mu \mathrm{L}$ extract; c) $+40 \mu \mathrm{L}$ std HS $\left.38.15 \mathrm{mg}_{-} \mathrm{SRFA} \mathrm{L}^{-1} ; \mathrm{d}\right)+40 \mu \mathrm{L}$ std ; e) $+40 \mu \mathrm{L}$ std. The electrochemical parameters are those described in the text. The deposition time is $90 \mathrm{~s}$. The $\mathrm{r}^{2}$ of the addition method titration curve is $0.9995(\mathrm{n}=12)$. The calculated peHS concentration is $845 \pm 29 \mu \mathrm{g}$-eq SRFA L ${ }^{-1}$. (b) Example of SEC analysis of an estuarine sample. a) Filter blank, b) Chromatogram of pSH analysis and c) Chromatogram of dHS analysis. The injected sample volume is $1 \mathrm{~mL}$.

\subsubsection{Multi-detection SEC analysis of dHS and pHS}

dHS and pHS concentration and composition were determined by multi-detection SEC. The technique used was developed by Huber et al. (1991) in the context of water treatment and 
adapted by Dulaquais et al. (2018b) for the analysis of estuarine and marine samples. The equipment was designed and assembled by DOC-Labour (Karlsruhe, Germany). The mobile phase which is a phosphate buffer solution at $\mathrm{pH}=6.85$ prepared by dissolving dibasic sodium phosphate (6g; EMSURE®, Merck, Germany, 99.5\%) and monobasic potassium phosphate (10g; EMSURE®, >99.5\%) in UP-water (4L). To remove dissolved inorganic carbon from samples an acid solution is added online before organic carbon analysis. This solution was prepared from orthophosphoric acid (16mL; EMSURE®, 85\%) and potassium peroxodisulfate (2g; Alfa Aesar, Ward Hill, MA, USA, 97\%) in UP-water (4L). The sample filtered on-line (0.45 $\mu \mathrm{m}$ PES filter, Sartorius, Goettingen, Germany), passes through the columns and is separated into 5 distinct fractions, with one of them being operationally defined as HS (Figure 2b). After separation, the sample is transported to a non-destructive UV detector (UVD, type S-200, Knauer, Berlin, Germany), whose wavelength is fixed at $254 \mathrm{~nm}$. The sample is then divided into two fractions. A fraction is carried to the organic carbon detector (Huber and Frimmel, 1991) and the other fraction to the organic nitrogen detector (K2001, Knauer, Berlin, Germany). The calibration of the carbon and UV detector was performed using potassium hydrogen phthalate $\left(\mathrm{C}_{8} \mathrm{H}_{5} \mathrm{KO}_{4}\right.$, Alfa Aesar, $\left.99.95-100.05 \%\right)$. The nitrogen detector was calibrated using potassium nitrate $\left(\mathrm{KNO}_{3}, \mathrm{EMSURE} \AA\right.$, > 90\%). Calibrations were conducted using five standard solutions with concentrations between 100 and $5000 \mu \mathrm{g}-\mathrm{C} . \mathrm{L}^{-1}$

and 14 and $700 \mu \mathrm{g}-\mathrm{N} . \mathrm{L}^{-1}$ prepared at different salinities according to Dulaquais et al. (2018b). The extinction coefficient of phthalate $\left(\varepsilon=1.63 \times 10^{3} \mathrm{~L} \mathrm{~mol}^{-1} \mathrm{~cm}^{-1}\right.$; Huber et al., 2011) was used to calibrate the spectral absorption coefficient (SAC) of the UV detector. Mass calibration for the determination of HS molecular weight was assessed as recommended by Hubert et al., (2011) from fulvic acids (SRFA 1S101F; IHSS) and humic acids (SRHA 1S101H; IHSS) from the Suwannee River. The aromaticity of HS is a calculated parameter, defined as the absorption of the HS fraction at 254nm over HS organic carbon concentration (Huber et al., 2011). The aromaticity of HS is directly related to the presence of aromatic carbon. In order to express the aromaticity as a percentage of aromatic carbon, we compared the SEC aromaticity obtained after analysing 8 IHSS standards with the percentage values of aromatic carbon provided by NMR from IHSS. Figure 3 shows a linear correlation between both variables $\left(\mathrm{r}^{2}=0.986, \mathrm{n}=8, p\right.$ value $\left.<0.005\right)$. According to this correlation, a unit of chromatographic aromaticity $\left(\mathrm{m}^{2} / \mathrm{g}-\mathrm{C}\right)$ corresponds to $4.4261 \%$ of aromatic carbon in the humic fraction. Detection limits (DL) were determined in irradiated UP- water and irradiated coastal seawater for an injected sample volume of $2 \mathrm{~mL}$. DL were 3 and $4 \mu \mathrm{g}-\mathrm{C} \mathrm{L} \mathrm{L}^{-1}$, 
respectively (Dulaquais et al., 2018b). The repeatability $(n=10)$ was $2 \%$ for a coastal seawater with a concentration of $551 \pm 12 \mu \mathrm{gC} \mathrm{L}^{-1}$.

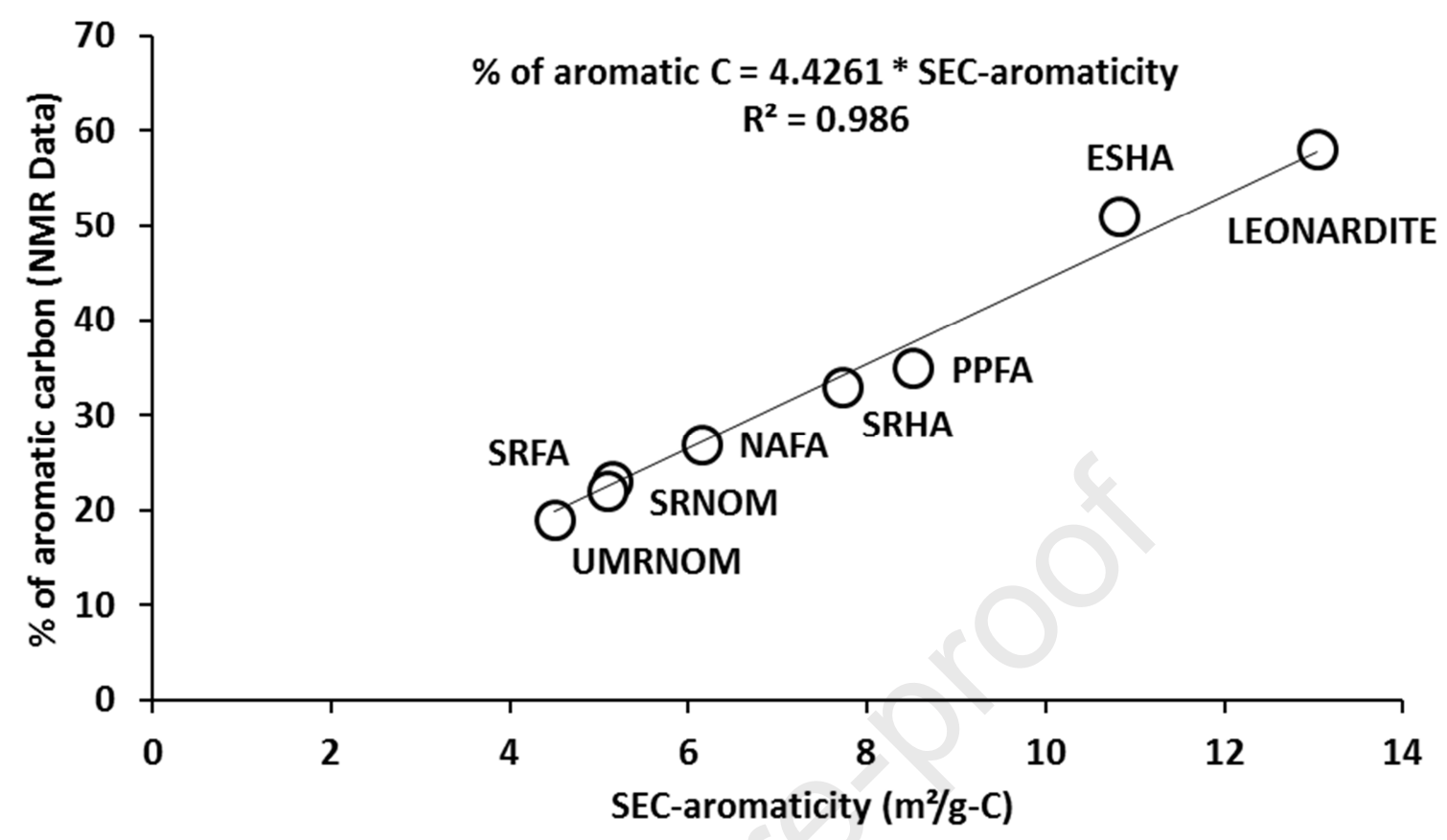

Figure 3. Correlation between the percentages of aromatic carbon (NMR data from International Humic Substances Society) and aromaticity determined by size exclusion chromatography $\left(\mathrm{m}^{2} / \mathrm{g}-\mathrm{C}\right)$ determined for 8 IHSS standards.

\section{3 pHS extraction procedure}

The IHSS has published a general procedure for the extraction, fractionation and characterization of HS. It has been adapted for natural water samples (Thurman and Malcolm, 1981, Baghoth et al., 2008) but also for soil samples (Swift, 1996). In the case of soil samples, a $0.1 \mathrm{M} \mathrm{NaOH}$ solution is used with a 10:1 liquid-to-solid ratio. The extraction is carried out under nitrogen atmosphere and stirring for at least 4 hours, then the mixture is left overnight. The supernatant containing HA and FA is recovered after centrifugation. The FA and HA are separated after acidification at $\mathrm{pH} 1(\mathrm{HCl})$ from the supernatant; the $\mathrm{HA}$ being insoluble at $\mathrm{pH}$ $<1$, remain in the precipitate while the FA remain in solution. In another context, Brym et al. (2014) used an extraction method developed by Osburnn et al. (2012) for the analysis of particulate organic matter collected on a filter. This procedure, called BEPOM (Base Extracted Particulate Organic Matter), combined with measurements of UV absorbance and fluorescence, has been successfully applied to the study of particulate organic matter in coastal ecosystems. Briefly, GF/F filters containing the particulate material are treated with a 
$0.1 \mathrm{M} \mathrm{NaOH}$ solution for 24 hours at $4^{\circ} \mathrm{C}$. The alkali solution obtained is then neutralized with an $\mathrm{HCl}$ solution and filtered at $0.2 \mu \mathrm{m}$. In the present work, we developed a pHS extraction protocol in 7 steps (Figure 4) drawing from these two latter procedures and we adapted it to analytical needs. After particles collection on GF/F filters (Whatman®; 25mm, step 1), filter samples were put in contact with $6 \mathrm{~mL}$ of $\mathrm{NaOH}$ solution $(0.1 \mathrm{M}$,) in $7 \mathrm{~mL}$ glass centrifuge tubes. Tubes were previously rinsed first with $\mathrm{HCl}$ solution $(0.01 \mathrm{M})$, then with $0.1 \mathrm{M} \mathrm{NaOH}$ solution and finally with UP-water. The filters were then crushed (step 2) with a cleaned $(0.1 \mathrm{M}, \mathrm{NaOH})$ metal rod until the filter fragments were about $1 \mathrm{~mm}$ diameter. Step 3 consists to wrap the tubes in aluminium foil to protect the samples from light and prevent degradation of the photosensitive part of the HS and placed on a shaking table (IKA® table KS 130 basic) at a speed of $240 \mathrm{rpm}$ for one night. After a minimum of 12 hours of contact, the samples were centrifuged $2 \mathrm{~min}$ at $3000 \mathrm{rpm}$ (step 4). After centrifugation, supernatant was collected with a cleaned syringe $(\mathrm{HCl} 0.01 \mathrm{M}, \mathrm{NaOH} 0.1 \mathrm{M}$, UP-water), filtered at $0.45 \mu \mathrm{m}$ (step 5) on an acid cleaned syringe filter (Rotilabo Sprintzenfilter, Roth ${ }^{\circledR}, \mathrm{CME}$ : Cellulose Mixed Ester) and placed in a precombusted glass vial $\left(450^{\circ} \mathrm{C}, 4 \mathrm{~h}\right)$. Before use, the syringe filters were rinsed with $100 \mathrm{~mL}$ of $0.01 \mathrm{M} \mathrm{HCl}$ and $100 \mathrm{~mL}$ of UP-water and the absence of contamination was checked through DOC analysis. The $\mathrm{pH}$ was finally lowered to $3.00 \pm 0.05$ (step 6) using small addition of $\mathrm{HCl}$ (ultrapure $\AA$, Merck 30\%) in order to prevent precipitation of both humic acids and metal oxyhydroxydes. The extracts were then stored in the dark at $4^{\circ} \mathrm{C}$ until analysis (step 7) by CSV or SEC. In order to validate this protocol, several tests were carried out : i) optimization of the extraction volume, ii) reaction time, iii) conditioning of the extracts, iv) reproducibility of the analyses and finally v) determination of the filter blanks and of the extraction efficiency. 
(1) Sampling and Filtration GF/F $25 \mathrm{~mm} \varnothing$ filter<smiles>CO</smiles>

(2)

Filter crushed in $6 \mathrm{~mL} 0,1 \mathrm{M}$ $\mathrm{NaOH}$ (Suprapure ${ }^{\circledR}$ )<smiles>[3H][3H]</smiles>

(3)

$$
\text { Shaking overnight }
$$
$12 h$, room $T^{\circ}$, dark<smiles>[Te][Te]</smiles>

(4)

$$
\text { Centrifugation }
$$$$
2 \text { min 3000rpm }
$$

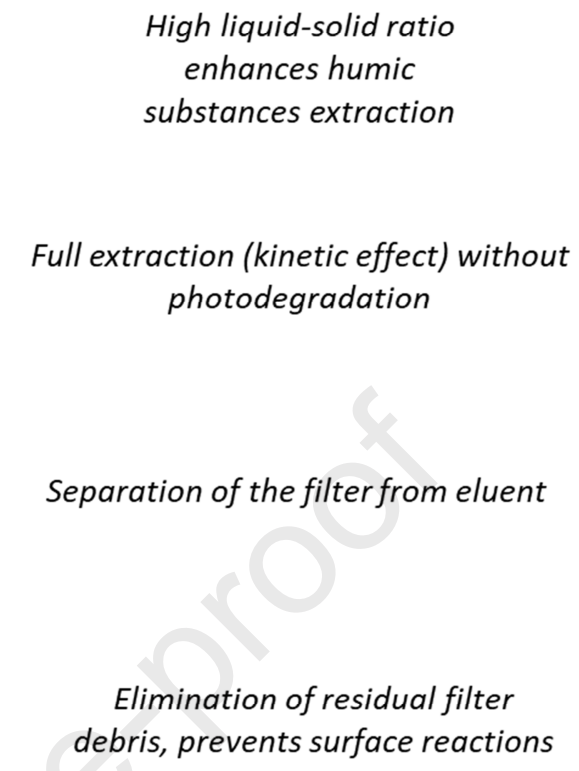

Filtration of supernatant $0,45 \mu \mathrm{m}$ PES seringue filter

(6)

(7)<smiles>[13CH3]</smiles>

Acidification of supernatant pH $3 \mathrm{HCl}$ (Ultrapure $\left.{ }^{\circledR}\right)$<smiles>[13CH3][TeH]</smiles>

Analysis SEC and CSV
Prevents

$\mathrm{Fe}$ (oxy)hydroxydes and Humic Acids precipitation

Quantification of humic substances and of their binding capacity

Figure 4. Method chart for the extraction of particulate humic substances from suspended particulate matter. Aims and advantages of the 7 steps are indicated.

\section{Results and discussion}

\subsection{Isolation and quantification of particulate humic substances}

\subsubsection{Optimization of extraction parameters.}

Tests were carried out on particles from freshwater $(S=0)$ and estuarine samples $(S=15)$ as well as on a certified reference material from the IHSS and examined following peHS analysis. The suspended particulate matter (SPM) load of the freshwater sample was $114.9 \pm$ $2.1 \mathrm{mg} \mathrm{L}^{-1}(\mathrm{n}=5)$. The first parameter studied was the extraction volume. For all extraction tests, the liquid-solid ratio used $(-100 \mathrm{~mL} \mathrm{NaOH}$ per $1 \mathrm{~g}$ of SPM) was about 10 times higher than the one recommended by the IHSS (10 $\mathrm{mL} \mathrm{NaOH}$ per $1 \mathrm{~g}$ of solid). This was done (1) to 
facilitate the extraction considering the large mass represented by the filter and (2) to get enough volume of extract to perform all subsequent analyses. Three filters were put in contact with three different extraction volumes: 2,4 and $6 \mathrm{~mL}$. It is worth noting that the three filters received a similar particle load which corresponded to a filtration of $186 \pm 11 \mathrm{~mL}$ of the freshwater sample. After 12 hours of contact between the $\mathrm{NaOH}$ solution and the filter, peHS extracted amounts were $67.3 \pm 4.1 ; 121.1 \pm 7.3$ and $112.0 \pm 6.7 \mu$ g-eqSRFA for extraction volumes of 2,4 and $6 \mathrm{~mL}$ respectively. If the amount of peHS recovered increased significantly from 2 to $4 \mathrm{~mL}$ (factor 1.8), the amount of pHS recovered with $6 \mathrm{~mL}$ was not significantly different from the ones using $4 \mathrm{~mL}$. $6 \mathrm{~mL}$ of extraction volume was thus considered to be sufficient and was used to perform all further peHS extractions. We note that freshwater, estuarine and marine particles may behaviour differently and thus may have different yield of recover. However considering our results, the potential limiting step for a good recovery of humic substances from the particulate phase seems to be the liquid-solid $(\mathrm{NaOH}$ vs SPM) ratio. The load of particles in seawater being very low $(<10 \mathrm{mg} / \mathrm{L}$; Abril et al., 2002), for the typical filtered volume in most marine studies (500-5000mL) an addition of $6 \mathrm{~mL}$ will correspond to a liquid-solid ratio ranging from 120 to $1200 \mathrm{~mL}$ per gram of solid. This ratio is 12 to 120 times higher than IHSS recommendations for terrestrial particles thereby the liquid-solid ratio in our method would be large enough for a good recovery of humic-like substances in seawater particles.

Next the reaction time and the preservation time of the extracts were both studied. To this purpose, two crushed filters were kept in contact with $\mathrm{NaOH}(0.1 \mathrm{M})$ under agitation for 30 min (sample1) and $12 \mathrm{~h}$ (sample 2). Then, after centrifugation, both extracts were filtered using an acid cleaned and rinsed syringe filter $(0.45 \mu \mathrm{m})$. Immediateley after filtration, $\mathrm{NaOH}$ was neutralized by lowering the $\mathrm{pH}$ to 3 in order to prevent further precipitation of both humic acids $(\mathrm{pH}<2)$ and metal hydroxydes $(\mathrm{pH}>4)$ that could induce a precipitation of HS through adsorption phenomena. The determination of peHS was then performed on the filtered and $\mathrm{pH}$ controlled extracts. The content of peHS from sample 1 (extraction time of 30 min) was $19.3 \pm 1.2 \mu \mathrm{g}$-eq SRFA and the content of peHS from sample 2 (extraction time of $12 \mathrm{~h}$ ) was $112.3 \pm 6.6 \mu \mathrm{g}$-eq SRFA. These results indicate a clear kinetic effect of the HS extraction with $\mathrm{NaOH}$ solution (Figure 5). It is therefore necessary to allow the reaction to take place for at least 12 hours, as recommended by the IHSS. The filtered and lowered $\mathrm{pH}$ extract from sample 2 (extraction time of $12 \mathrm{~h}$ ) was then kept at $4^{\circ} \mathrm{C}$ in the dark and peHS were then measured on different aliquots after 2, 3 and 11 days of storage (Figure 5). The amount of peHS in these 3 aliquots, i.e. $134.8 \pm 8.0,126.2 \pm 7.4$ and $128.0 \pm 7.6$ were not 
significantly different. The SE on the average of the four determinations from the sample 2 extract (including days 1 to 11 ) was $7.7 \%$ with all values being equivalent when uncertainties were considered with a $95 \%$ confidence interval $\left(n=4\right.$, tvalue $\left._{0.05}=2.132\right)$. Considering our experiments, an extraction of $\mathrm{pHS}$ on a $25 \mathrm{~mm} \mathrm{GF} / \mathrm{F}$ filter using $6 \mathrm{~mL}$ of $\mathrm{NaOH}$ requires a reaction time of $12 \mathrm{~h}$. The extract that was centrifuged, filtered and whose $\mathrm{pH}$ was lowered can be considered stable over time, for at least 11 days. It is worth noting that $\mathrm{N}_{2}$ degassing of the extract did not show any improvement of the extraction yield and was not included in the final extraction procedure.

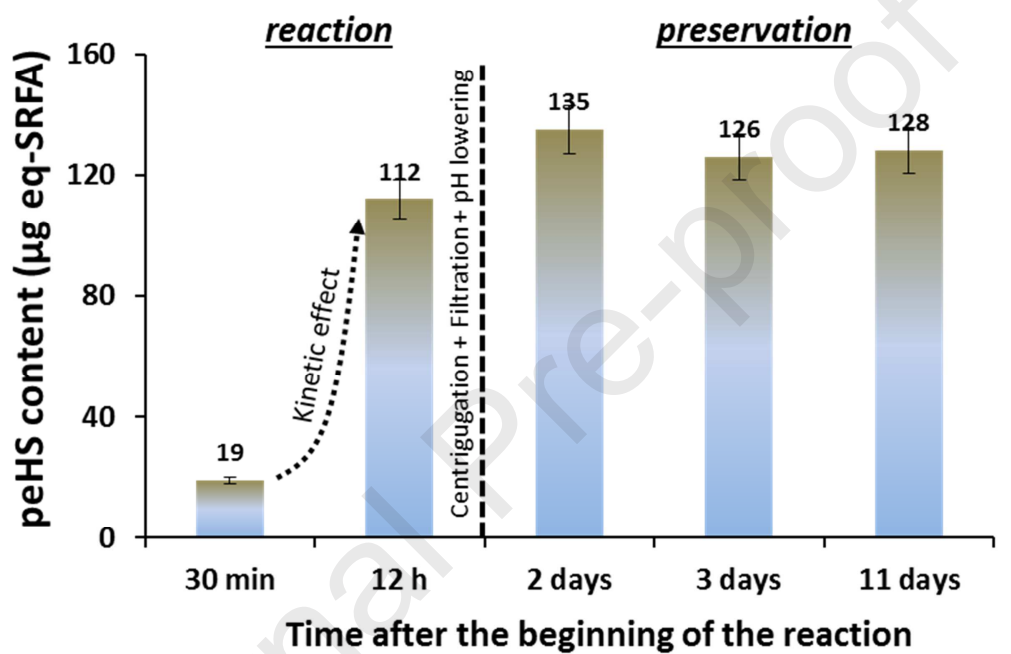

Figure 5. Evolution of peSH in the particulate extract (expressed in $\mu \mathrm{g}$ of equivalent SRFA) as a function of extraction reaction time (left) and of preservation time (right). All experiments where operated on a sample from the Aulne estuary $(S=0)$.

\subsubsection{Analytical performance}

Filter blank analyses were performed by applying the extraction protocol described above to precombusted filters. The peHS content measured in the treated extracts was $0.54 \pm 0.06 \mu \mathrm{g}$ eq-SRFA $(n=3)$. Considering the elemental carbon composition of the SRFA standard (i.e. $52.44 \%$ ), this concentration corresponds to $0.28 \pm 0.03 \mu \mathrm{g}-\mathrm{C}$. Multi-detection SEC analysis of the same extracts gave a quantity of carbon on the filter of $0.9 \pm 0.1 \mu \mathrm{g}-\mathrm{C}$. In estuarine samples, the filter blank represented $6 \pm 6 \%(n=20)$ of the pHS recovered and all data presented in the next sections were blank corrected.

In order to assess the efficiency of the extraction, a mass of $199.7 \pm 0.1 \mu \mathrm{g}$ of SRFA standard (1S101F, IHSS) was placed on a filter (GF/F 25mm, precombusted) and extracted following the procedure described above. The mass used for this experiment was representative of 
typical particle loads obtained after filtration of estuarine samples. Analyses of this extract showed a recovery of $96 \pm 3 \%$ and $100 \% \pm 3 \%$ for the electrochemical and multi-detection SEC methods, respectively.

Analytical repeatability was assessed by measuring 3 times 6 distinct aliquots of the same centrifuged, filtered and lowered $\mathrm{pH}$ extract (estuarine sample: $\mathrm{S}=15$, filtered volume $200 \mathrm{~mL}$ ). The peHS content of the alkali extract varied between 114.8 and 135.6 with an average of $125.2 \pm 9.4 \mu \mathrm{g}$ eq-SRFA $(\mathrm{n}=18)$. The repeatability was then $7.5 \%$. The reproducibility was determined by the analysis of three centrifuged, filtered and lowered $\mathrm{pH}$ extracts obtained from three distinct filters that collected particles from the same water sample (estuarine sample, $\mathrm{S}=10$, filtered volume $=200 \mathrm{~mL}$ ). The results varied between 204 and 211 $\mu \mathrm{g}$ eq-SRFA with an average value of $207.6 \pm 2.8 \mu \mathrm{g}$ eq-SRFA $(\mathrm{n}=9)$. The reproducibility was thus estimated to $1.3 \%$. The higher relative SE on the repeatability test (vs reproducibility test) was unexpected but we relate this to the different concentrations between the two samples. The higher the concentration of peHS, the lower the SE is. Considering the different tests conducted the protocol for the extraction and quantification of particulate humic substances proposed in this work is repeatable and reproducible.

\subsection{Distributions and speciation of humic substances in the Aulne estuary}

Twenty dissolved and particulate samples were collected along the land-sea continuum of the Aulne River-Bay of Brest system (Figure 1). We applied the extraction method developed in this work and determined humic substances concentrations using electrochemical and SEC methods. According to the terminology of Table 1, four HS fractions were determined: total dissolved HS (dHS), dissolved electroactive HS (deHS), total particulate HS (pHS) and particulate electroactive HS (peHS). All concentrations were converted into humic organic carbon concentrations using the volumes filtered (for particulate samples) and the carbon content of the standard used for electrochemical measurements (1S101F, 52.44\%). The mixing diagrams (concentrations versus salinity) of the four HS fractions are shown in Figure 6.

At time of sampling, DOC ranged between $1.07 \pm 0.10 \mathrm{mg}_{-} \mathrm{C} \mathrm{L}^{-1}$ in the Iroise Sea and 7.20 \pm $0.40 \mathrm{mg}_{-} \mathrm{C} \mathrm{L}^{-1}$ in the Aulne River (Figure 6a). The distribution of DOC was nearly conservative $\left(\mathrm{DOC}\left(\mathrm{mg}-\mathrm{C} \mathrm{L}^{-1}\right)=-0.17 * \mathrm{~S}+7.90 ; \mathrm{R}^{2}>0.96 ; \mathrm{p}\right.$ value $\left.<0.05\right)$, suggesting that mixing between fresh and marine waters was the dominant process. However this distribution may hide internal processes such as removal of specific classes of organic compounds (induced by flocculation and or bacterial degradation) compensated by external 
(sediment/particulate release) or internal inputs (size class transfer within DOM) as previously observed in the same estuary (Dulaquais et al., 2018b). The contribution of dHS (assumed to be the total pool of dissolved humic substances, Table 1) to DOC was determined to be $63.6 \pm$ $7.1 \%$ along the estuary. This percentage was almost constant all along the salinity gradient (Figure 6a) with the exception of the MTZ where the HS contribution was lower (56\%) and in the most marine part of the estuary ( $>$ > 34) where HS accounted for $72 \%$ of the DOC. These variations indicate the existence of internal dynamics behind the apparent conservative distribution of DOC in these part of the land-sea continuum.

dHS and deHS concentrations ranged respectively from $846 \pm 51$ and $77 \pm 5 \mu \mathrm{g}_{-} \mathrm{C} \mathrm{L}^{-1}$ in the Iroise Sea $(S=35.2)$ to $4399 \pm 264$ and $3250 \pm 195 \mu \mathrm{g}-\mathrm{C} \mathrm{L}^{-1}$ in the Aulne River $(\mathrm{S}=0)$. The deHS concentration ranges were similar to those reported by Pernet-Coudrier et al., (2013) and by Marie et al., (2017) in the Aulne estuary; dHS concentration ranges were similar to those reported by Dulaquais et al., (2018b) in this system. The dHS concentrations showed a quasi-conservative distribution in the estuary (Figure 6b). The concentrations gradually decreased from freshwaters to marine waters with a slight «loss type » negative anomaly between 2 to 8 of salinity. The equation of the theoretical dilution line obtained between the two end-members (dHS $\left.\left(\mu \mathrm{g}-\mathrm{C} \mathrm{L} \mathrm{L}^{-1}\right)=-101.0 * \mathrm{~S}+4408\right)$ suggests a dHS deficit of $\sim 5 \%$ (corresponding to $\sim 200 \mu \mathrm{g}-\mathrm{C} \mathrm{L}^{-1}$ ) in this part of the estuary where the MTZ was located (Figure 1). By contrast, deHS showed a strong non-conservative distribution in the estuary with a sharp negative anomaly observed in the MTZ (Figure 6b). Considering the deHS theoretical dilution line (deHS $\left.\left(\mu \mathrm{g}-\mathrm{C} \mathrm{L} \mathrm{L}^{-1}\right)=-90.2 * \mathrm{~S}+3258 \mu \mathrm{g}-\mathrm{C} \mathrm{L}^{-1}\right)$ the losses of deHS between 2 and 8 of salinity reached $\sim 40 \%$ (corresponding to $\sim 1 \mathrm{mg}_{-} \mathrm{C} \mathrm{L}^{-1}$ ) indicating a stronger removal of deHS compared to dHS in the MTZ.

The concentrations of pHS and peHS ranged respectively from $30.2 \pm 1.8$ and $3.1 \pm 0.2 \mu \mathrm{g}-\mathrm{C}$ $\mathrm{L}^{-1}$ in the Iroise Sea $(\mathrm{S}=35.2)$ to $946 \pm 57 \mu \mathrm{g}-\mathrm{C} \mathrm{L}^{-1}$ and $1018 \pm 61 \mu \mathrm{g}-\mathrm{C} \mathrm{L}^{-1}$ at salinity 5.2. pHS and peHS distributions were very similar (Figure 6c). The mixing diagrams of the two particulate fractions (e.g. electroactive and total) both showed a strong non-conservative behaviour with a high positive «source type» anomaly in the MTZ. At 5.2 of salinity enrichments up to 700 and $800 \%$ over the theoretical dilution lines ( $\mathrm{pHS}=-3.5 * \mathrm{~S}+153 \mu \mathrm{g}-\mathrm{C}$ $\mathrm{L}^{-1}$ and peHS $=-4.3 * \mathrm{~S}+155 \mu \mathrm{g}-\mathrm{C} \mathrm{L}^{-1}$ ) were estimated for $\mathrm{pHS}$ and peHS respectively. These results show that particulate humic substances can constitute a significant fraction of humic substances in estuarine systems, with peHS representing $~ 35 \%$ of eHS (deHS + peHS) in the MTZ. 
The very significant increase in pHS and peHS concentrations in this MTZ can be explained by two different mechanisms: (1) the accumulation of resuspended sediments in the MTZ that increase the HS particle load and/or (2) a transfer of eHS under flocculation from the dissolved to the particulate phase. From a quantitative point of view, the deHS losses $(\sim 1000$ $\mu \mathrm{g}-\mathrm{C} \mathrm{L}^{-1}$ ) appeared to be balanced by peHS inputs in the MTZ. Therefore, a phase transfer under flocculation seems to be the main mechanism to consider.

Figure $6 \mathrm{~d}$ describes the percentage of electroactive HS (to total HS) as a function of salinity for the dissolved and particulate phases. Within a large part of the estuary $(1<S<29)$, half of dHS were electroactive ( $48 \pm 5 \%, \mathrm{n}=14$ ). This percentage rose up to $74 \%$ in freshwater but decreased to $26 \pm 2 \%(\mathrm{n}=4)$ at the end of the mixing zone $(33<\mathrm{S}<34)$. In marine endmember $(\mathrm{S}=35.2)$, this contribution was $9 \%$. Such a low value for marine waters is consistent with previous results showing a contribution of deHS to dHS varying between 4 and $15 \%$ along the water column in open marine environments (Dulaquais et al., 2018a). For the particulate phase, the contribution of eHS to HS varied even more substantially with salinity (Figure 6d). In the upstream part of the estuary $(0<\mathrm{S}<11)$ all pHS could be considered electroactive $(104 \pm 5 \% ; n=7)$. This contribution sharply decreased in the inner estuary $(13<S<26$, Figure $6 d)$ and only $10.4 \pm 0.2 \%(n=5)$ of the pHS were electroactive at the highest salinities $(29<\mathrm{S}<35.2)$. When compared to the theoretical dilution curves, the percentage of electroactive HS (\% eHS) in the dissolved and the particulate phases were non conservative (Figure 6d). Strong "loss type" anomalies were observed between 0 and 26 of salinity in the dissolved fraction and between 10 and 35 in the particulate fraction. This indicates distinct behaviours between electroactive and non-electroactive HS within the two physical phases. 
(a)

(b)
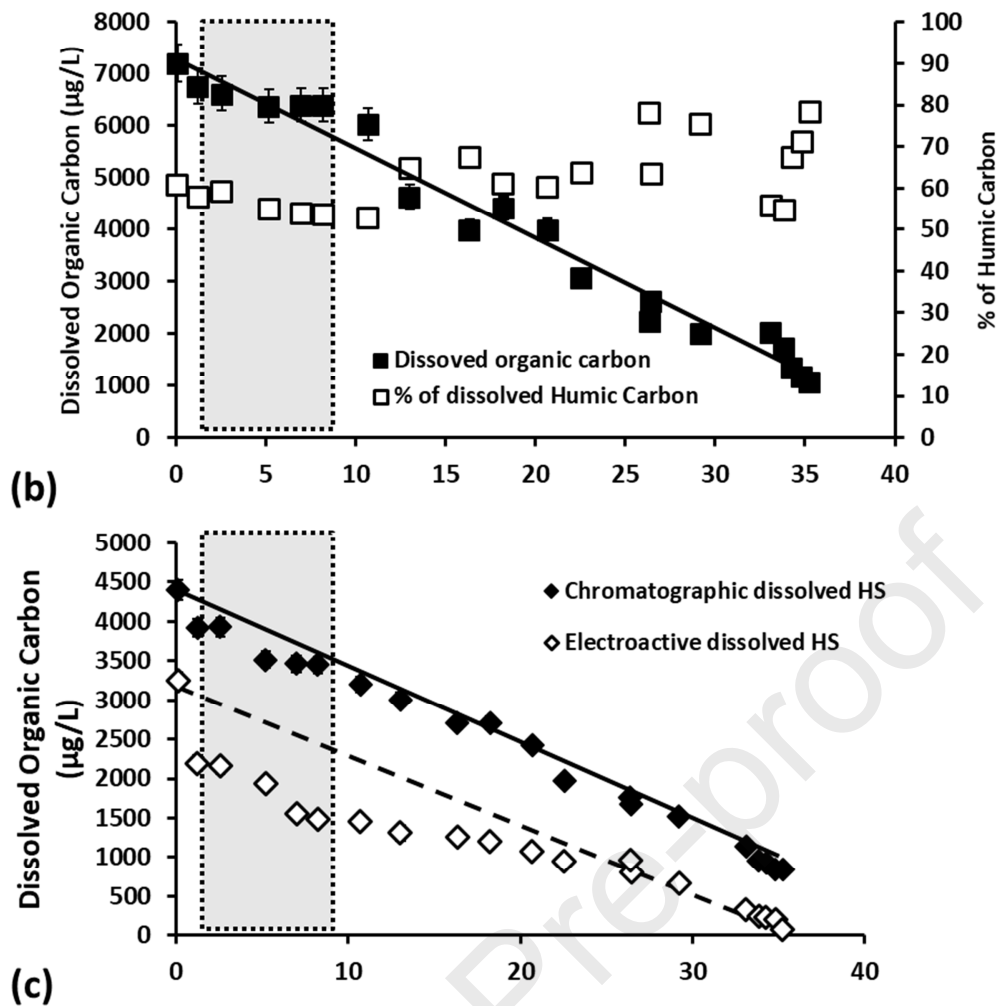

(c)

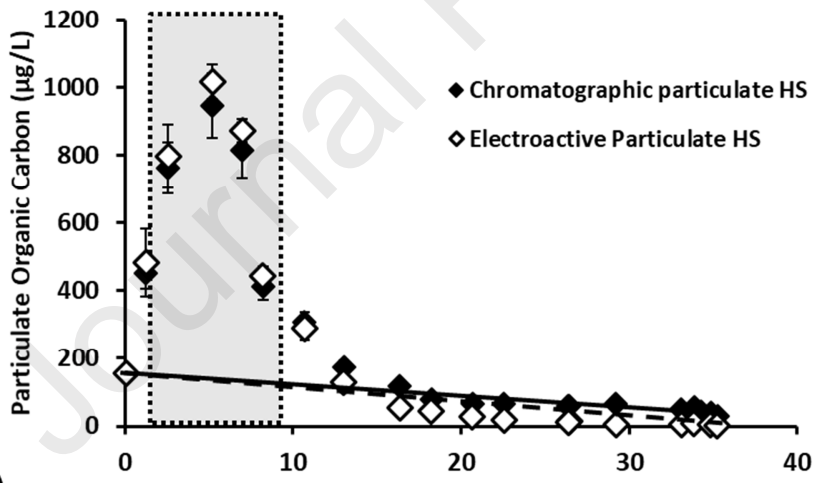

(d)

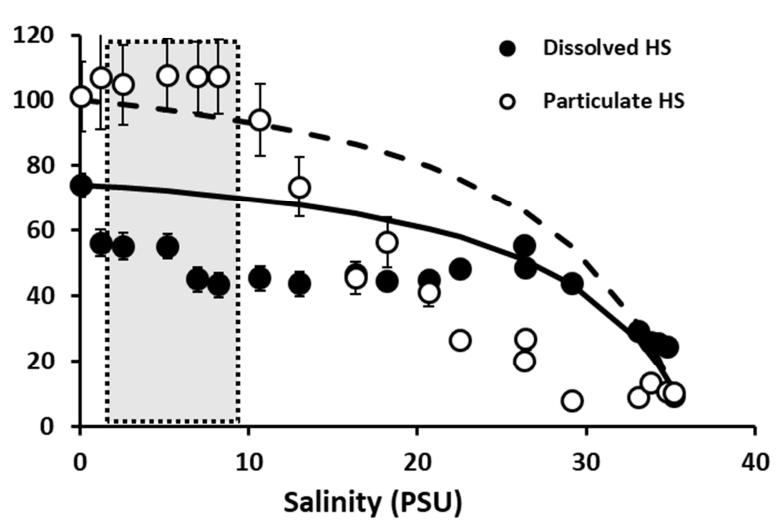

Figure 6. Mixing diagrams of a) Dissolved organic carbon (DOC) and the contribution of dHS to DOC b) $\mathrm{dHS}$ and deHS, c) pHS and peHS, d) Percentage of electroactive HS (\% of eHS) with salinity The lines indicate theoretical conservative mixing lines. The grey areas indicate the maximum turbidity zone (MTZ). 


\subsection{Characterization of dissolved and particulate humic substances in riverine and marine endmembers}

Mean molecular weight (MW), aromatic carbon content (\% AC) and $\mathrm{C} / \mathrm{N}$ elemental ratio of dissolved and particulate HS were also determined following SEC chromatography measurements. Over the whole salinity gradient, MW was in the 640-725 Da range for dHS and 620-850 Da for pHS (Figure 7a). The \% AC in HS ranged from 1 to $22 \%$ for both dHS and pHS (Figure $7 \mathrm{~b}$ ) and elemental $\mathrm{C} / \mathrm{N}$ ratios varied between 25 and 55 for $\mathrm{dHS}$ and between 7 and 30 for pHS (Figure 7c). Table 2 summarizes the differences of composition between the dHS and the pHS collected in the river and marine waters. First, it is worth noting that the characteristics of dHS in the Aulne River (MW=719 Da, \% $A C=22.4$ and $\mathrm{C} / \mathrm{N}=26)$ were very similar to those reported by Dulaquais et al. (2018b). In the marine endmember, dHS characteristics $(\mathrm{MW}=625 \mathrm{Da}, \% \mathrm{AC}=1.86$ and $\mathrm{C} / \mathrm{N}=47.5)$ were also similar to those reported by Dulaquais et al. (2018b) with the exception of $\mathrm{C} / \mathrm{N}$ that was found to be significantly higher here than the one reported before (i.e. 15). The high $\mathrm{C} / \mathrm{N}$ of 47.5 observed here in late summer (as compared to the $\mathrm{C} / \mathrm{N}$ of 15 observed in spring) must be related to the nitrate limitation in the Iroise Sea $\left(\mathrm{NO}_{3}{ }^{-}<0.2 \mu \mathrm{M}\right)$. In such conditions, dHS may be used as a pool of bioavailable nitrogen for autotrophic phytoplankton (See et al., 2006) inducing an increase of the $\mathrm{C} / \mathrm{N}$ of $\mathrm{dHS}$.

Table 2: Characteristics of dissolved (dHS) and particulate (pHS) humic substances collected in the Aulne River and in the Iroise Sea. With \%eHS, the percentage of electroactive HS (fraction able to complex trace elements); MW the mean nominal molecular weight; \% AC, the percentage of aromatic carbon and $\mathrm{C} / \mathrm{N}$, the elemental carbon o nitrogen ratio.

\begin{tabular}{|c|c|c|c|c|}
\hline \multirow{2}{*}{} & \multicolumn{2}{|c|}{ Aulne River } & \multicolumn{2}{c|}{ Iroise Sea } \\
\cline { 2 - 5 } & dHS & pHS & dHS & pHS \\
\hline \% eHS & 73.8 & 100.0 & 8.9 & 10.2 \\
\hline MW (Da) & 719 & 796 & 625 & 702 \\
\hline \% AC & 22.4 & 22.6 & 1.86 & 1.0 \\
\hline C/N & 26.2 & 9.8 & 47.5 & 7.0 \\
\hline
\end{tabular}

When comparing the characteristics of pHS to that of dHS, pHS of the Aulne River had a similar aromatic carbon content to that of dHS (22.6 vs 22.4) but were of higher MW (796 Da $v s 719 \mathrm{Da})$ and also appeared enriched in nitrogen compared to dHS (C/N=9.8 vs 26.2). On the other hand, marine pHS had a higher MW value (702 Da $v s 625)$ than that of $\mathrm{dHS}$, a C/N 
ratio (7.0) close to the Redfield ratio and were poorly aromatic (\% $\mathrm{AC}=1.0$ ). These results indicate that similarly to dHS, pHS are characterised by a decrease of both MW and \% AC from freshwaters to marine waters. Dittmar and Kattner (2003), that studied dHS in an arctic estuary using the same type of chromatographic equipment, made similar observations. These authors attribute the decrease in MW during freshwater-seawater mixing to the intramolecular contraction induced by the increase of both ionic strength and concentration of divalent ions. Dulaquais et al., (2018b) and Breiteinstein (2019) also observed a decrease of aromaticity from riverine to marine waters in the Aulne estuary.

Environmental pHS data are scarce and to our knowledge there is no pHS data acquired by a multi-detection SEC or electrochemical system, making it difficult to compare our results with other studies. Calace et al. (2010), in a study about the distribution of dissolved and particulate HS in the Ross Sea, found C/N ratios of $20.3 \pm 4.6$ and $12.2 \pm 2.4$ for $\mathrm{dHS}$ and pHS respectively. Their results indicate that marine pHS are enriched in nitrogen when compared to dHS similarly to what we report here. The $\mathrm{C} / \mathrm{N}$ value we measured in the marine sample (7.0) indicates a composition of pHS that was tightly linked to primary production at the time of sampling.

\subsection{Abiotic processes involving $d H S$ and pHS along the mixing zone}

The strong positive anomaly of pHS in the MTZ has been related to a transfer under flocculation of eHS from the dissolved to the particulate phase (see 3.2). SEC chromatographic analyses indicated that in the MTZ, pHS were of high molecular weight (> $850 \mathrm{Da})$, electroactive (100\%), highly aromatic (values higher than theoretical mixing curve) and also enriched in nitrogen (Figures $6 \mathrm{c}$ and 7). This is in line with the characteristics of deHS (with high MW, high aromaticity and low $\mathrm{C} / \mathrm{N}$ ratios) and thus supports the hypothesis of a phase transfer of eHS under flocculation. As dHS concentrations appeared almost conservative along the salinity gradient (Figure $6 \mathrm{~b})$, the strong loss of deHS in the MTZ $(\sim 1$ mg-C. $\left.\mathrm{L}^{-1}\right)$ implies an input of non-electroactive dissolved HS to counterbalance this loss. In the absence of any obvious sources within the water column, we relate this input of nonelectroactive dissolved HS to benthic inputs. The properties of dHS in the MTZ showed a slight decrease of MW (Figure 6a), a deficit of aromaticity to the theoretical mixing curve (Figure 6b) and an increase of the $\mathrm{C} / \mathrm{N}$ ratio (Figure $7 \mathrm{c}$ ). All these trends suggest that the benthic dSH transferred to the water column are of lower MW, more aliphatic and less enriched in nitrogen functional groups than the terrestrial dHS directly brought by the river. 
The negative anomaly of \% eHS observed between 10 and 35 of salinity in the particulate phase (Figure 6d) also deserves an explanation. Because pHS were all electroactive at salinities lower than 10, a small $\left(60 \mu \mathrm{g}-\mathrm{C} . \mathrm{L}^{-1}\right)$ input of non electroactive pHS must have occurred between 15 and 30 of salinity to balance the deficit of peHS (Figure 6d). Aggregation and subsequent flocculation of the dissolved non-electroactive HS released in the MTZ is probably the most valid hypothesis to explain such an input. Nevertheless SEC measurement uncertainties (3\%) prevent from depicting a significant loss type anomaly of dSH induced by a small flocculation $\left(60 \mu \mathrm{g}-\mathrm{C} . \mathrm{L}^{-1}\right)$.

\subsection{Biotic processes involving $d H S$ and $p H S$ along the mixing zone}

The mixing diagram of $\mathrm{C} / \mathrm{N}$ ratios indicated positive anomalies for both the dissolved and particulate fractions of HS (Figure 7c). In the MTZ, the $\mathrm{C} / \mathrm{N}$ positive anomaly for the dissolved HS can be related to the above-described abiotic mechanisms: i.e. (1) the flocculation of N-rich eHS and/or (2) the benthic input of N-depleted non-eHS (see 3.4).

Alternatively, the increasing $\mathrm{C} / \mathrm{N}$ anomaly downstream the MTZ ( $>10)$ should be related to biotic processes. We attribute this increase of the $\mathrm{C} / \mathrm{N}$ ratio to a cumulative preferential nitrogen uptake (compared to carbon) by heterotrophic bacteria along estuarine mixing. During estuarine transit, the nitrogen content of HS may have been specifically uptaken by "free" and particulate-coated bacteria resulting in HS becoming more and more N-depleted in the dissolved and particulate fraction respectively. This preferential $\mathrm{N}$ uptake has induced the intense deficit of nitrogen, compared to carbon, in the dissolved and particulate humic material we observed in the last stage of mixing (Figure 7c). This process was probably enhanced by a long period a solar irradiance before sampling that maintained estuarine waters to relatively high temperatures $\left(\mathrm{T}^{\circ}>15^{\circ} \mathrm{C}\right)$ favourable to bacterial development. Such decoupling between carbon and nitrogen uptake have been previously observed in phytoplankton and bacterial cultures growing on humic substrates (Hunt et al., 2000; See et al., 2006). 
(a)

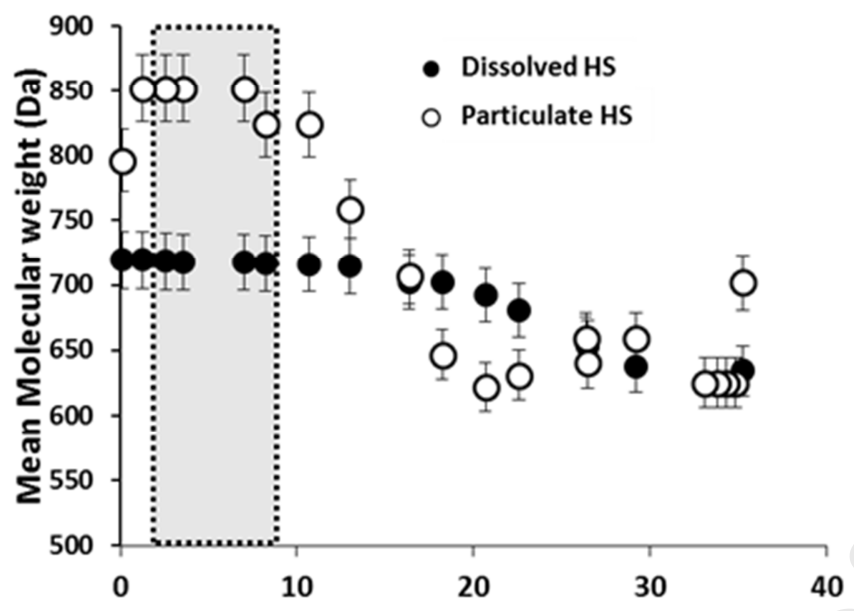

(b)

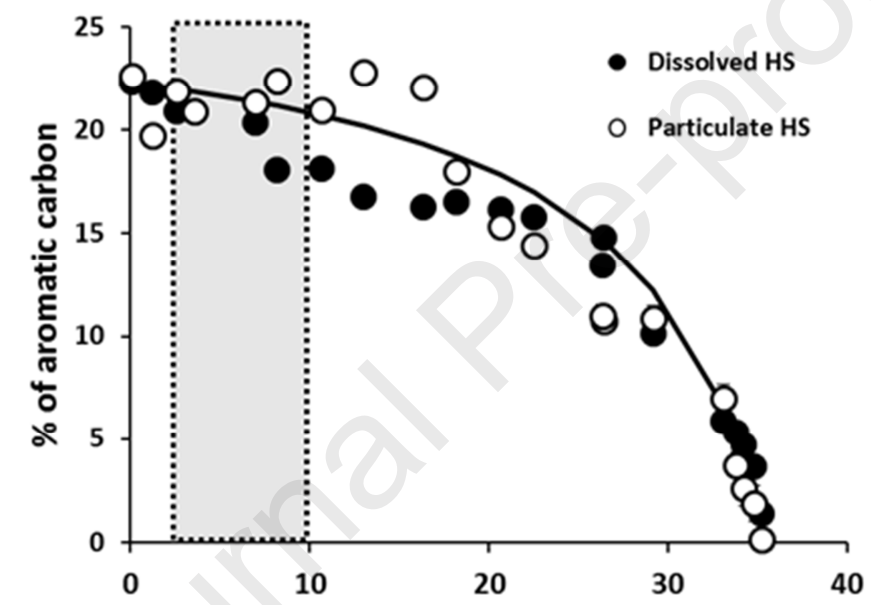

(c)

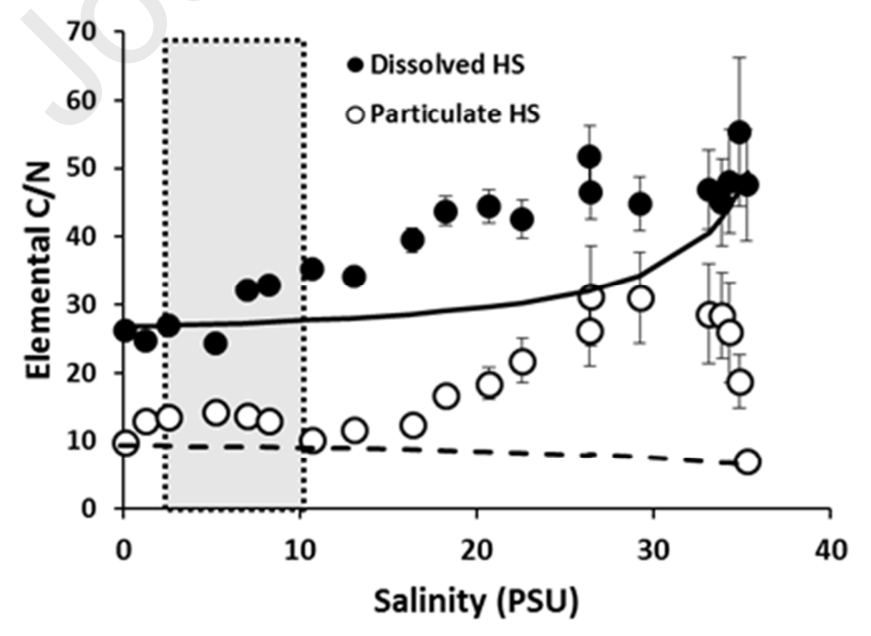

Figure 7. Mixing diagrams of a) Mean Molecular Weight (Da), b) \% of aromatic carbon (the black line indicates the theoretical dilution line for both fractions) and c) Elemental $\mathrm{C} / \mathrm{N}$ ratios (The black and dashed lines indicate the theoretical dilution line for dissolved HS and particulate HS, respectively). The greyed areas in the various figures indicate the maximum turbidity zone. 


\section{Conclusions}

In this work, a simple solid-liquid extraction method combined with electrochemical and multi-detection SEC analysis was developed to study the physical partitioning, the speciation, and the chemical composition of humic substances (HS) in natural waters. The extraction conditions as well as the protocol to preserve the extracts were optimized and validated using a certified reference material (IHSS standard). The performances of the method allowed the study of the distribution of particulate HS (pHS) along the land-sea continuum.

The analysis of natural samples collected along the entire salinity gradient of a macrotidal estuary allowed, for the first time, to study the phase partitioning (dissolved vs particulate), the speciation of HS (electroactive vs non-electroactive) and the composition (mean nominal molecular weight, aromaticity and $\mathrm{C} / \mathrm{N}$ ratio) of HS. Distinct characteristics between freshwater HS and marine HS were identified and non-conservative distributions with salinity in both phases were observed. The analysis of HS composition in the two phases confirmed the existence of internal biotic and abiotic processes in addition to pure mixing. An intense source of pHS in the MTZ was observed. Electrochemical analyses allowed to identify these pHS as originating from the dissolved phase by flocculation of eHS in the early stage of mixing. The MTZ was also identified as a source of non-eHS released from porewater. The latter were transported across the estuary and induced an apparent conservative distribution of dissolved HS (dHS). Deficits of nitrogen, compared to carbon, in dissolved and particulate HS were identified along estuarine mixing. We related this feature to a use of HS as a bioavailable nitrogen reservoir for heterotrophic bacteria and or estuarine phytoplankton suggesting that HS may not be as recalcitrant as thought. Considering the role of HS in trace element geochemistry and in bacterial nutrition, the study of particulate HS should be now more documented.

\section{Acknowledgements}

We warmly thank Jérôme Lepioufle for typesetting corrections. This work is a contribution to the FeLINE project (Fer Ligands In the aulNe Estuary, Ifremer, Politique de site DS, 20192020) and was funded by Ifremer, grant numbre R204-12-MS-02. 


\section{References}

Abbt-Braun, G., Lankes, U., Frimmel. F., 2004. Structural characterization of aquatic humic substances The need for a multiple method approach. Aquat. Sci. 66, 151-170.

Abril, G., Nogueira, M. , Etcheber, H., Cabeçadas, G., Lemaire E., Brogueira, M. J. 2002. Behaviour of Organic Carbon in Nine Contrasting European Estuaries ; Est. Coast. and Shelf Sci., 54, 241-262.

Abualhaija,M.M., Whitby, H., van den Berg, C.M.G., 2015. Competition between copper and iron for humic ligands in estuarine waters. Mar. Chem. 172, 46-56.

Aiken, G., McKnight, D., Wershaw R., and MacCarthy P., 1985. In : Humic substances in soil, sediment and water: Gochemistr, Isolation and Characterization., Wiley, New York, N.Y., (Ed.) 622 pp.

Aiken, J., Brown, P., A., Noyes, T. I., Pickney, D., J., Molecular size and weight of fulvic and humic acids from Suwannee River R.C. Averett, J.A. Leenheer, D.M. McKnight, K.A. Thorn (Eds.), Humic Substances in the Suwannee River, Georgia: Interactions, Properties, and Proposed Structures, U.S. Geological Survey (1989), pp. 163-180

Open File Report 87-557

Amann, T., Weiss, A., Hartmann, J. 2014. Inorganic Carbon Fluxes in the Inner Elbe Estaury, Germany.Est. and Coast, 38 (1) 192-210.

Asmala, E., Bowers, D.G., Autio, R., Kaartokallio, H., D.N. Thomas, D.N., 2014. Qualitative changes of riverine dissolved organic matter at low salinities due tu flocculation. J. Geophys. Res. Biogeosci. 119, 1919-1933.

Bassoulet, P, 1979. Etude de la dynamique des sediments en suspension dans l'estuaire de l'Aulne (Rade de Brest). Thèse de Doctorat. Université de Bretagne Occidentale 136pp.

Baghoth, S.A., Maeng, S.K., .Salinas-Rodriguez, S.G., Ronteltap, M., Sharma, S., Kennedy, M., Amy, G.L., 2008. An urban water cycle perspective of natural organic matter (NOM): NOM in drinking water, wastewater effluent, storm water, and seawater. Water Sci. and Tech. : Water Supply. 8,701707.

Blasioli, S., Braschi, I., Pinna, M. V., Pusino, A., and Gessa. C.E. 2008. Effect of undesalted dissolved organic matter from compost on persistence, adsorption and mobility of cyhalofop herbicide in soils. J. Agric. Food Chem. 56, 4102-4111.

Breitenstein, J., Application de la chromatographie d'exclusion stérique multi-détection à l'étude de la spéciation de la matière organique dissoute en milieu estuarien et côtier. Autre. Université de Bretagne occidentale - Brest, 2019. Français. 〈NNT : 2019BRES0074). 〈tel-02956331〉

Brenon, I., Le Hir, P., 1999. Modelling the turbidity maximum in the Seine Estuary (France) : Identification of formation precesses. Est. Coast. and Shelf Sci., 49 525-544.

Brym, A., Paerl, H. W., Montgomery, M. T., Handsel L T., Ziervogel K., Osburn, C. L., 2014. Optical and chemical characterization of base extracted particulate organic matter in coastal marine environnements. Mar. Chem. 162, 96-113.

Bundy, R.M.,.Abdulla, H.A., Hatcher, P.G., Biller, D.V., Buck, K.N., and Barbeau. K.A. 2015. Ironbinding ligands and humic substances in the San Francisco Bay estuary and estuarine-influenced shelf redgions of coastal California. Mar. Chem. 173, 183-194.

Calace, N., Palmieri, N., Mirante, S., Petronio, B.M., Pietroletti, M., 2006. Dissolved and particulate humic substances in water channels in the historic centre of Venice Waters Res. 40, 1109-1118.

Calace, N., Casagrande, A., Mirante, S., Petronio, B.M., Pietroletti, M., 2010. Distribution of humic substances dissolved and particulated in wayer column in Ross Sea, Antarctica. Microchem. J., 96, 218-224.

Chanudet, V., Fillela, M., Quentel, F. 2006. Application of a simple voltammetric method to determination of refractory organic substances in freshwaters. Anal. Chim. Acta, 569, 244-249.

Coble, P.G., 1996. Characterisation of marine and terrestrial DOM in seawater using excitation-emission matrix spectroscopy. Mar.Chem. 51, 325-346.

Dittmar, T., Kattner, G., 2003. Recalcitrant dissolved organic mùatter in the ocean : major contribution of small amphiphilics. Mar. Chem. 82, 115-123.

Dulaquais, G., Waeles, M., Gerringa, L., Middag, R., Rijkenberg, M., Riso, R., 2018a. The biogeochemistry of electroactive humic substances and its connection to iron chemistry in the north east atlantic and the western mediterranean sea. J. of Geoph. Res.: Oceans. 123 5481-5499.

Dulaquais, G., Breitenstein, J., Waeles, M., Marsac, R., Riso, R., 2018b. Measuring dissolved organic matter in estuarine and marine waters: size-exclusion chromatography with various detection methods. Environ. Chem. 15, 436-449. 
Dulaquais, G., Waeles, M., Breitenstein, J., Knoery J., Riso. R., 2020. Links between size fractionation, chemical speciation of dissolved copper and chemical speciation of dissolved organic matter in the Loire estuary. Environm. Chem. https://doi.org/10.1071/EN19137.

Ertel, J.R., Hedges, J.I., Devol, A.H., Richey J.E., Ribeiro, M.D.N.G., 1986. Dissolved humic substances of the Amazon River system. Limn. and Oceanog. 31,739-754.

Fillela, M., 2014. Understanding what we are measuring: Standars and quantification of natural organic matter. Water Res. 50, 287-293.

Gagnon, R., Levasseur, M., Weise, A.M., Fauchot, J., Campbell P.G.C., Weissenboeck, B. J., Marzouk, A., Gosselin M., and Vigneault. B., 2005. Growth stimulation of Alexandrium Tanarense (Dinophyceae) by humic substances from the manicougan river (Eastern Canada) J. Phycol. 41, 489-497.

Gao, Z., \& Guéguen, C. (2018). Distribution of thiol, humic substances and colored dissolved organic matter during the 2015 Canadian Arctic GEOTRACES cruises. Marine Chemistry, 203, 1-9.

Hair, M. E., \& Bassett, C. R. (1973). Dissolved and particulate humic acids in an east coast estuary. Estuarine and Coastal Marine Science, 1(1), 107-111.

Harvey, H. R., \& Mannino, A. (2001). The chemical composition and cycling of particulate and macromolecular dissolved organic matter in temperate estuaries as revealed by molecular organic tracers. Organic Geochemistry, 32(4), 527-542.

Hessen, D. O., and L. J. Tranvik. 1998. Aquatic humic sub-stances. Springer-Verlag, New York, New York, USA

Huber, S. A., Frimmel, F. H., 1991. Flow injection Analysis of Organic and Inorganic Carbon in the Lowppb range. Anal. Chem. 63, 2122-2130.

Huber, S.A., Balz, A., Albert, M., Pronk, W., 2011. Characterisation of aquatic humic and non humic matter with size-exclusion chromatography organic carbon detection organic nitrogen detection (LC-OCD-OND). Water Res. 45, 879-885.

Huguet, A., Vacher, L., Relexans, S., Saubusse, S., Froidefond J.M., Parlanti, E., 2009. Properties of fluorescent dissolved organic matter in the Gironde estuary. Org. Chem. 40, 706-719.

Hunt, A. P., Parry, J. D., \& Hamilton $\square$ Taylor, J. (2000). Further evidence of elemental composition as an indicator of the bioavailability of humic substances to bacteria. Limnology and Oceanography, 45(1), 237-241.

Laglera, L.M., Battaglia, G., van den Berg, C.M.G., 2007. Determination of humic substances in natural waters by cathodic stripping voltammetry of their complexes with iron. Anal. Chim. Acta, 599(1), 58-66.

Laglera, L.M., Battaglia, G., and van den Berg, C.M.G., 2011. Effect of humic substances on the iron speciation in natural waters by CLE/CSV. Mar. Chem. 127, 134-143.

Leenheer, J.A., Croué, J.P., 2003. Characterizing dissolved aquatic organic matter. To better treatment of drinking water. Environmental Science and Technology. 37(1), 18A-26A.

Marie, L., Pernet-Coudrier, B., Waeles, M., Riso, R., 2017. Seasonal variation and mixing behavior of glutathione, thioacetamide and fulvic aciods in a temperate macrotidal estuary (Aulne, NW France) Est. Coast. And Shelf. Sci., 184,177-190.

McDonald, S., Bishop, A.G., Prenzler, P.D., Robards. K., 2004. Analytical chemistry of freshwater humic substances. Anal. Chim. Acta 527, 105-124.

Miano, T.M., Senesi, N., 1992. Synchronous excitation fluorescence spectroscopy applied to soil humic substances chemistry. Sci. Total Environ. 117/118, 41-51.

Middelburg, J. J., Herman, P. M. J., 2007. Organic matter processing in tidal estuaries. Mar. Chem. 106, 127-147.

Moreda-Piñeiro, A., Seco-Gesto, E.M., Bermejo-Barrera, A., Bermejo-Barrera. P., 2006. Characterisation of surface marine sediments from Ria de Arousa estuary according to extractable humic matter content. Chemosphere 64, 866-873.

Osburn, C. L., Handsel, L. T., Mikan, M. P., Pearl, H. W., Montgomery, M. T., 2012. Fluorescence tracking of dissolved and particulate organic matter quality in a river-dominated estuary. Environ. Sci. Technol. 46 (16) 8628-8636.

Parlanti, E., Wörz, K., Geoffroy, L., Lamotte, M., 2000. Dissolved organic matter fluorescence spectroscopy as a tool to estimate biological activity in a coastal zone submitted to anthropogenic inputs. Org. Chem. 31, 1765-1781. 
Pernet-Coudrier, B., Waeles, M., Fillela, M., Quentel, F., Riso, R., 2013. Simple and simultaneous determination of glutathione, thioacetamide and refractory organic matter in natural waters by DPCSV. Sci. of the Tot ; Environ. 463, 997-1005.

Quentel, F., Madec, C., Le Bihan A., Courtot-Coupez, J. 1986. Determination des substances humiques en milieu marin par redissolution cathodique à l'électrode à goutte pendante de mercure. Anal. Lett. 19(3-4), 325-344.

Savoye, N., David, V., Morisseau, F., Etcheber, H., Abril, G., Billy, I., Charlier, K., Oggian, G., Derriennic, H., Sautour, B., 2012. Origin and composition of particulate organic matter in a macrotidal turbid estuary : The Gironde Estuary (France) Est. Coast. and Shelf Sci., 108,16-28.

See, J. H., Bronk, D. A., \& Lewitus, A. J. (2006). Uptake of Spartina $\square$ derived humic nitrogen by estuarine phytoplankton in nonaxenic and axenic culture. Limnology and Oceanography, 51(5), 2290-2299.

Senesi, N., 1990. Molecular and quantitative aspects of the chemiqstry of fulvic acid and its interactions with metal ions and organic chemicals. Anal. Chim. Acta 232, 51-75.

Shank, G.C., Skrabal, S.A., Whitehead R.F., Brooks Avery, G., Kieber. R. J.,2004. River discharge of strong $\mathrm{Cu}$-complexing ligands to South Atlantic Bight waters. Mar. Chem. 88, 41-51.

Sholkovitz, E., Boyle E., Price, N.B., 1978. The removal of dissolved humic acids and iron during estuarine mixing. Earth and Plan. Sci. Lett. 40, 130-136.

Stevenson F J 1994 Humus Chemistry: Genesis, Composition,Reactions. John Wiley \& Sons, New York. $496 \mathrm{p}$.

Sukekava, C., Downes, J., Slagter, H.A., Gerringa, L.J.A., Laglera L. M., 2019. Determination of the contribution of humic substances to iron complexation in seawater by catalytic cathodic stripping voltammetry. Talanta $189,359-364$.

Swift, R. S., 1996. Organic matter characterization. In Sparks, D.L. (Ed.). Methods of soil analysis, Soil Science Society of America Book Serie 5. 1011-1069.

Tanaka, S., Kiyoshi, O., Fukushima, M., Nakayasu, K., Hasebe, K., 1997. Water solubility enhahcement of ptrene in the presence of humic substances. Anal. Chim. Acta 337, 351-357.

Thurman, E., Malcolm, R., 1981. Preparative isolation of aquatic humic substances. Environ. Sci. Technol. $15,463-466$.

Voelker, B.M., Kogut, M.B., 2001. Interpretation of metal speciation data in coastal waters: the effects of hjumic substances on copper bindfing as a test case. Mar. Chem. 74, 303-318.

Waeles, M., Riso, R., Pernet-Coudrier, B., Quentel, F., Durrieu G., Tyssot, C. 2013. Annual cycle of humic substances in a temperate estuarine system affected by agricultural practices. Geochim. and Cosmochim. Acta 106, 231-246.

Waeles, M., Tanguy, V., Riso, R., 2015. On the control of copper collopidal distribution by humic substances in the Penzé estuary. Chemosphere 119, 1176-1184.

Whitby, H., van den Berg, C.M.G., 2015. Evidence for copper-binding humic substances in seawater. Mar. Chem. 173, 282-290.

Whitby, H., Planquette, H., Cassar, N., Bucciarelli, E., Osburn, C. L., Janssen, D. J., ... \& Sarthou, G. (2020). A call for refining the role of humic-like substances in the oceanic iron cycle. Scientific reports, 10. doi.org/10.1038/s41598-020-62266-7 


\section{Highlights:}

A simple method for the determination of humic substances in suspended particulate matter is developed and validated.

Application of the method to estuarine samples allows the quantification and the characterization of particulate humic substances along the entire land-sea continuum of a temperate system.

Internal abiotic and biotic estuarine processes alter the chemical composition of humic substances during estuarine mixing. 


\section{Declaration of interests}

$\bigotimes$ The authors declare that they have no known competing financial interests or personal relationships that could have appeared to influence the work reported in this paper.

$\square$ The authors declare the following financial interests/personal relationships which may be considered as potential competing interests: 